\title{
GAMBARAN PENGETAHUAN ORANG TUA TENTANG DIET MAKANAN TERHADAP KARIES GIGI PADA SISWA/I KELAS IV SD NEGERI NO. 060891 JL. JAMIN GINTING 303 MEDAN
}

\author{
Ngena Ria, Susy Adrianelly Simaremare \\ Jurusan Keperawatan Gigi Poltekkes Kemenkes Medan
}

\begin{abstract}
Abstrak
Makanan atau subrat merupakan unsur penting untuk terjadinya karies. Proses karies ditentukan oleh jenis karbohidrat dalam bentuk tepung atau cairan yang bersifat lengket serta hancur didalam mulut yang memudahkan terjadinya karies. Hampir semua anak menyukai makanan yang bersifat kariogenik yang merupakan salah satu penyebab terjadinya karies. Penelitian bersifat deskriptif yang bertujuan untuk mengetahui Gambaran Pengetahuan Orang Tua Tentang Diet Makanan Terhadap Karies Gigi Pada Siswa/I SD Negeri No. 060891 Jl. Jamin Ginting 303 Medan Tahun 2014 yang dilaksanakan pada September sampai Nopember 2014. Jumlah sampel sebanyak 30 orang. Hasil penelitian Gambaran Pengetahuan Orang Tua Tentang Diet Makanan terhadap karies Gigi diperoleh data sebanyak 24 orang $(80 \%)$ memiliki pengetahuan baik, 6 orang (20\%) memiliki pengetahuan sedang dan tidak terdapat siswa yang berpengetahuan buruk. Hasil pengetahuan untuk karies gigi susu diperoleh jumlah def-t adalah 47 dan def-t rata-rata 1,56. Hasil penelitian untuk karies Gigi tetap diperoleh jumlah DMF-T adalah 41 dan DMF-T rata-rata 1,36. Berdasarkan hasil yang dapat disimpulkan bahwa Gambaran Pengetahuan Orang Tua Tentang Diet Makanan Terhadap Karies Gigi Pada siswa/i Kelas IV SD Negeri No. 060891 Jl. Jamin Ginting 303 Medan Tahun 2014 diperoleh hampir semua anak menyukai makanan dan minuman yang bersifat kariogenik yang merupakan faktor resiko terjadinya karies. Dari data hasil penelitian menunjukkan hampir seluruh siswa/I memiliki karies gigi $(83,4 \%)$. Karies gigi susu diperoleh data def-t adalah 47 dengan rata-rata def-t 1,56. Karies gigi tetap diperoleh jumlah DMF-T adalah 41 dan rata-rata DMF-T 1,36. Diharapkan terutama kepada siswa/i agar memilih makanan yang menyehatkan gigi untuk menghindari terjadinya karies gigi.
\end{abstract}

Kata kunci : Pengetahuan orang tua, diet makanan, karies gigi

\section{Latar Belakang}

Untuk mewujudkan tujuan derajat kesehatan masyarakat yang optimal, telah banyak upaya dan program yang dilaksanakan secara menyeluruh oleh pemerintah bersama masyarakat, baik program yang bersifat promotif, preventif dan kuratif. Kesehatan merupakan faktor penting yang dapat menentukan kualitas sumber daya masyarakat, kesehatan gigi dan mulut merupakan suatu bagian dari kesehatan umum yang mempunyai peran penting dalam fungsi pengunyahan dan estetika.

Menurut Undang-undang No.23 tahun 1992 Bab 1 pasal 3 tentang kesehatan menyebutkan bahwa tujuan pembangunan kesehatan adalah untuk meningkatkan kesadaran, kemauan hidup sehat bagi setiap orang agar terwujud derajat kesehatan masyarakat yang optimal.

Kesehatan gigi dan mulut merupakan bagian dari kesehatan tubuh yang tidak dapat dipisahkan satu dengan yang lainnya. Kesehatan gigi dan mulut akan mempengaruhi kesehatan tubuh keseluruhan. Gigi merupakan salah satu bagian tubuh yang berfungsi untuk mengunyah, berbicara dan mempertahankan bentuk muka. Berdasarkan fungsi gigi, maka setiap individu dapat melaksanakan pemeliharaan kesehatan gigi sedini mungkin agar dapat bertahan lama dalam rongga mulut.

Penyakit gigi dan mulut di Indonesia yang paling banyak dijumpai adalah karies. Karies atau gigi berlubang adalah kerusakan pada struktur jaringan keras gigi (email, dentin) yang diakibatkan oleh asam yang dihasilkan oleh bakteri yang terdapat pada plak gigi.

Penyakit karies masih banyak terjadi pada anakanak. Kesehatan gigi anak kurang mendapat perhatian dari orang tua, karena adanya anggapan bahwa gigi susu pada anak akan diganti oleh gigi tetap. Orang tua kurang menyadari bahwa dampak yang ditimbulkan sebenarnya akan sangat besar bila tidak dilakukan perawatan. Akibat yang dapat terjadi bila sejak awal gigi telah mengalami karies terganggunya fungsi gigi sebagai pengunyah, yang mengakibatkan terjadinya malnutrisi sehingga mempengaruhi kecerdasan anak.

Makanan atau substrat merupakan salah satu unsur penting untuk terjadinya karies. Makanan pokok manusia adalah karbohidrat. Jenis karbohidrat yang paling dapat merusak gigi adalah sukrosa. Proses karies ditentukan oleh jenis karbohidrat dalam bentuk tepung atau cairan yang bersifat lengket serta mudah hancur didalam 
mulut lebih memudahkan timbulnya karies. Hampir semua anak mempunyai faktor risiko terhadap karies yang bila dimakan dan diminum yang bersifat kariogenik yang merupakan faktor risiko terhadap karies yang bila dimakan diantara jam makan.

Berdasarkan latar belakang, maka peneliti ingin mengetahui Gambaran Pengetahuan Orang Tua Tentang Diet Makanan Terhadap Karies Gigi Pada Siswa/i Kelas IV SD Negeri No 060891 Jl. Jamin Ginting 303 Medan Tahun 2014

\section{Tujuan Penelitian}

Tujuan Umum

Penelitian bertujuan untuk mengetahui Gambaran Pengetahuan Orang Tua tentang Diet Makanan terhadap Karies Gigi Pada Siswa/i Kelas IV SD Negeri No 060891 Jl. Jamin Ginting 303 Medan Tahun 2014.

\section{Manfaat Penelitian}

Dari hasil penelitian ini diharapkan dapat memberi manfaat

1. Untuk menambah wawasan orang tua tentang diet makanan dalam mencegah karies gigi pada siswa/i SD Negeri No 060891 Jl. Jamin Ginting 303 Medan Tahun 2014.

2. Sebagai bahan masukan pada pihak sekolah agar melakukan kerja sama dengan pihak puskesmas dalam pelaksanaan UKGS untuk meningkatkan kesehatan gigi dan mulut.

3. Untuk informasi data bagi peneliti lain dan sebagai bahan referensi di perpustakaan jurusan

Keperawatan Gigi Politeknik Kesehatan Medan.

\section{Jenis dan Desain Penelitian}

Jenis penelitian adalah penelitian deskriptif dengan metode survey yang bertujuan untuk mengetahui Gambaran Pengetahuan orang Tua tentang Diet Makanan terhadap Karies Gigi pada Siswa/i SD Negeri No 060891 Jl. Jamin Ginting 303 Medan Tahun 2014.

\section{Populasi Penelitian}

Populasi penelitian adalah keseluruhan objek penelitian atau objek yang diteliti. Populasi adalah Siswa/i SD Negeri No 060891 Jl. Jamin Ginting 303 Medan Tahun 2014.

\section{Sampel Penelitian}

Sampel adalah sebagian yang diambil dari keseluruhan objek yang diteliti dan dianggap mewakili seluruh populasi. Dalam penelitian ini sampel adalah Siswa/I kelas IV SD Negeri No 060891 Jl. Jamin Ginting 303 yang berjumlah 30 orang.

\section{Hasil Penelitian}

Setelah melakukan penelitian Gambaran Pengetahuan Orang Tua tentang Diet Makanan terhadap Karies Gigi pada Siswa/i Kelas IV SD Negeri No. 060891 Jl. Jamin Ginting 303 Medan Tahun 2014 diperoleh hasil sebagai berikut :
Tabel 1

Gambaran Pengetahuan Orang Tua tentang Diet Makanan terhadap Karies Gigi pada Siswa/i kelas IV SD Negeri No. 060891 Jl. Jamin Ginting 303 Medan Tahun 2014

\begin{tabular}{lcc}
\hline $\begin{array}{l}\text { Kriteria } \\
\text { Pengetahuan }\end{array}$ & $\begin{array}{c}\text { Jumlah siswa } \\
(\mathbf{n})\end{array}$ & $\begin{array}{c}\text { Persentase } \\
(\boldsymbol{\%})\end{array}$ \\
\hline Baik & 24 & 80 \\
Sedang & 6 & 20 \\
Buruk & 0 & 0 \\
Jumlah & 30 & 100 \\
\hline
\end{tabular}

Dari tabel 1 dapat diketahui bahwa dari 30 siswa/i Kelas IV SD Negeri No. 060891 Jl. Jamin Ginting 303 Medan Tahun 2014, yang memiliki pengetahuan baik sebanyak 24 orang (80\%), pengetahuan sedang 6 orang (20\%), dan tidak ada siawa/i yang berpengetahuan buruk.

Tabel 2

Distribusi Frekuensi Karies Gigi Susu pada siswa/i kelas IV SD Negeri No. 060891 Jl. Jamin ginting 303 Medan Tahun 2014

\begin{tabular}{cccccc}
\hline $\begin{array}{c}\text { Jumlah } \\
\text { Siswa }\end{array}$ & & Karies & & Jumlah & def-t \\
\hline & d & E & F & def-t & $\begin{array}{c}\text { Rata- } \\
\text { rata } \\
\text { 30 }\end{array}$ \\
\hline
\end{tabular}

Dari tabel 2 dapat diketahui bahwa dari 30 siswa/i, jumlah def-t adalah 47 dan def-t rata-rata 1,56.

Tabel 3

Distribusi Frekuensi Karies Gigi Tetap pada siswa/i kelas IV SD Negeri No.060891 Jl. Jamin ginting 303 Medan Tahun 2014.

\begin{tabular}{cccccc}
\hline $\begin{array}{c}\text { Jumlah } \\
\text { Siswa }\end{array}$ & & Karies & & Jumlah & DMF-T \\
\hline & D & M & F & DMF-T & $\begin{array}{c}\text { Rata- } \\
\text { rata }\end{array}$ \\
$\mathbf{3 0}$ & 38 & 3 & 0 & 41 & 1,36 \\
\hline
\end{tabular}

Berdasarkan tabel 3 diperoleh data dari 30 siswa/i, jumlah DMF-T adalah 41 dan DMF-T rata-rata adalah 1,36

\section{Pembahasan}

Kesehatan gigi dan mulut merupakan bagian dari kesehatan tubuh yang tidak dapat dipisahkan satu dengan yang lainnya. Kesehatan gigi dan mulut akan mempengaruhi kesehatan tubuh keseluruhan. Gigi merupakan salah satu bagian tubuh yang berfungsi untuk mengunyah, berbicara dan mempertahankan bentuk muka. Berdasarkan fungsi gigi, maka setiap individu dapat melaksanakan pemeliharaan kesehatan gigi sedini mungkin agar dapat bertahan lama dalam rongga mulut. Penyakit gigi dan mulut di Indonesia yang paling banyak dijumpai adalah karies. Karies atau lubang adalah kerusakan pada struktur jaringan keras gigi ( email, dentin) yang diakibatkan oleh asam yang dihasilkan oleh bakteri yang terdapat pada plak gigi. 
Pengetahuan merupakan hasil tahu dan ini terjadi apabila seseorang telah melakukan penginderaan rerhadap suatu objek. Penginderaan terjadi melaluai pancaindra, yakni: indera penglihatan, pendengaran, penciuman, rasa dan raba. Sebagian besar pengetahuan manusia diperoleh melalui mata dan telinga.Pengetahuan merupakan hal yang sangat penting dalam pembentukan tindakan seseorang.

Diet makanan sehat adalah makanan yang mengandung zat-zat yang di butuhkan oleh tubuh kita. Diet yang baik untuk kesehatan umum, juga baik untuk kesehatan gigi. Susunan makanan sehari-hari sebaiknya mengikuti anjuran empat sehat lima sempurna. Diet dalam kesehatan gigi dapat dilihat dalam beberapa segi, pertama efek makanan didalan rongga mulut yaitu efek lokal pada waktu makanan dikunyah sebagai tahap awal pencernaan.

\section{Kesimpulan}

Berdasarkan hasil penelitian Gambaran Pengetahuan Orang Tua Tentang Diet Makanan Terhadap Karies Gigi Pada Siswa/i Kelas IV SD Negeri No. 060891 Jl. Jamin Ginting 303 Medan Tahun 2014 diperoleh sebagai berikut:

1. Pengetahuan terutama kriteria baik yaitu sebanyak 24 orang $(80 \%)$.

2. Karies gigi pada siswa/i diperoleh data jumlah deft adalah 47 dan rata-tara def-t 1,56. Dan jumlah DMF-T adalah 41 dengan rata-rata DMF-T 1,36.

3. Dari hasil diketahui DMF-T lebih kecil dari target nasional $(\leq 2)$.

\section{Saran}

1. Diharapkan kepada orang tua agar lebih memperhatikan anak dalam memilih jenis makanan yang baik dikonsumsi, seperti memakan makanan yang banyak mengandung serat.

2. Kepada anak agar memilih jenis makanan yang menyehatkan gigi.

3. Diharapkan kepada orang tua agar lebih memperhatikan anak dalam memilih jenis makanan yang baik dikonsumsi, seperti memakan makanan yang banyak mengandung serat.

4. Kepada anak agar memilih jenis makanan yang menyehatkan gigi.

\section{DAFTAR PUSTAKA}

Boediharjo., 1985. Pemeliharaan Kesehatan Gigi Keluarga. Airlangga: Surabaya.

Ibrahim, Kasir., 1992. Kamus Pintar Amanah: Surabaya.

kidd,M,A.,2002.Dasar-Dasar Karies Penyakit dan Penanggulangannya. Buku Kedokteran EGC: Jakarta.

Mary E.Beck., 1992. Ilmu Gizi dan Diet. Andi: Jakarta.

Tarigan, A., 1990. Karies Gigi. Hipokrates: Jakarta.

Politeknik Kesehatan Medan, 2012 Panduan Penyusunan Karya Tulis Ilmiah, USU. Medan.

Putri, M.H.,E Herijulianti dan N Nurjannah, 2012. Ilmu Pencegahan Penyakit Karies dan Jaringan Pendukung Gigi. Jakarta:EGC

Pintauli,s dan T Hamada,2008. Menuju Gigi dan Mulut Sehat Pencegahan dan Pemeliharaan. Medan: USU Press.

Pratiwi, D., 2009. Gigi sehat dan cantik. PT Kompas Media: Jakarta.

Rakyat, Dian., 2010. Perawatan Gigi Anak. Dian Rakyat: Jakarta. 